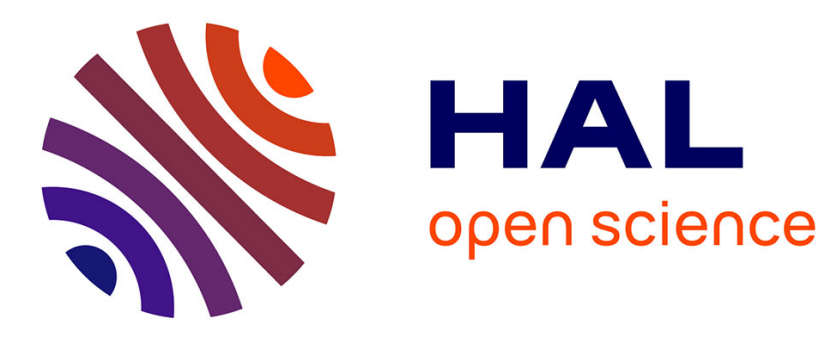

\title{
Chemically Detachable Polyelectrolyte Multilayer Platform for Cell Sheet Engineering
}

Armelle Chassepot, Longcheng Gao, Isabelle Nguyen, Alexandre Dochter, Florence Fioretti, Patrick Menu, Halima Kerdjoudj, Corinne Baehr, Pierre Schaaf, Jean-Claude Voegel, et al.

\section{To cite this version:}

Armelle Chassepot, Longcheng Gao, Isabelle Nguyen, Alexandre Dochter, Florence Fioretti, et al.. Chemically Detachable Polyelectrolyte Multilayer Platform for Cell Sheet Engineering. Chemistry of Materials, 2011, 24 (5), pp.930-937. 10.1021/cm2024982 . hal-02481289

\author{
HAL Id: hal-02481289 \\ https://hal.science/hal-02481289
}

Submitted on 17 Feb 2020

HAL is a multi-disciplinary open access archive for the deposit and dissemination of scientific research documents, whether they are published or not. The documents may come from teaching and research institutions in France or abroad, or from public or private research centers.
L'archive ouverte pluridisciplinaire HAL, est destinée au dépôt et à la diffusion de documents scientifiques de niveau recherche, publiés ou non, émanant des établissements d'enseignement et de recherche français ou étrangers, des laboratoires publics ou privés. 


\section{Chemically detachable polyelectrolyte multilayer platform for cell sheet engineering}

Armelle Chassepot ${ }^{1,2}$, Longcheng Gao ${ }^{3, \perp}$, Isabelle Nguyen ${ }^{1,2}$, Alexandre Dochter ${ }^{6}$, Florence Fioretti ${ }^{1,2}$, Patrick Menu ${ }^{4}$, Halima Kerdjoudj ${ }^{5}$, Corinne Baehr ${ }^{3}$, Pierre Schaaf ${ }^{6}$, Jean-Claude Voegel,2,*, Fouzia Boulmedais $^{6}$, Benoit Frisch ${ }^{3}$ and Joëlle Ogier ${ }^{1,2, *}$

1. Institut National de la Santé et de la Recherche Médicale, INSERM Unité 977, Faculté de Chirurgie Dentaire, 11 Rue Humann, 67085 Strasbourg Cedex, France

2. Université de Strasbourg, Faculté de chirurgie dentaire, 1 place de l'Hôpital 67000 Strasbourg.

3. Laboratoire de Conception et Application de Molécules Bioactives, UMR 7199, CNRS/Université de Strasbourg, Faculté de Pharmacie, 74 route du Rhin, 67401 Illkirch Cedex, France.

4. Group of Bioengineering (UMR CNRS 7561), UHP-Nancy 1, Faculté de Médecine, 9 avenue de la forêt de Haye 54500 Vandoeuvre-lès-Nancy, France.

5. Institut National de la Santé et de la Recherche Médicale, INSERM, UMR-S 926, IFR 53 URCA, UFR-Odontologie, 1 avenue du Maréchal Juin, 51095 Reims Cedex, France.

6. Institut Charles Sadron, Université de Strasbourg, Centre National de la recherche scientifique, UPR 22, 23 rue du Loess, 67034 Strasbourg Cedex, France.

$\perp$ Present Address: Key Laboratory of Bio-inspired Smart Interfacial Science and Technology of Ministry of Education, School of Chemistry and Environment, Beihang University, Beijing, 100191, P.R. China

* Corresponding author: Jean-Claude.Voegel@medecine.u-strasbg.fr, Joelle.Ogier@ medecine.u-

$\underline{\text { strasbg.fr }}$

Keywords: layer-by-layer, disulfide bond, sacrificial platform, human gingival fibroblasts, autologous cell sheet, wound healing, contractile phenotype 


\begin{abstract}
Human gingival fibroblasts (HGFs) cell sheets have a potential use for in vivo wound healing due to the ability of HGFs to adopt a contractile phenotype which is typically expressed during extracellular matrix tissue remodeling. For this purpose, we developed a chemically detachable platform based on poly(allylamine hydrochloride)/poly(styrene sulfonate) multilayer film built on a sacrificial precursor film which served as a substrate for HGF cell layer formation. The sacrificial precursor film, based on disulfide-containing polycation and polyanion, is degradable under mild conditions compatible for cell sheet detachment. Cellular viability and cell phenotype analysis of HGF show that the designed platform promotes cell phenotype switch into contractile phenotype, maintained after cell sheet lift-off. This contractile phenotype is acquired by fibroblasts during in vivo wound healing and tissue remodeling. HGFs cell sheet fragments, obtained by this detachment process, could be cultured later on showing a good retention of the typical spindle-shape of differentiated cells after 10 days of culture. HGFs cell sheets have great potential applications as autologous substrates for tissue repair and cellular synthetic platforms for research on connective tissue diseases or evaluation of novel therapeutic agents.
\end{abstract}



Armelle Chassepot, Longcheng Gao,
Isabelle Nguyen, Alexandre Dochter, Florence Fioretti, Patrick Menu, Halima Kerdjoudj, Corinne Baehr, Pierre Schaaf, Jean-Claude Voegel*, Fouzia Boulmedais, Benoit Frisch, Joëlle Ogier*

Chemically detachable polyelectrolyte multilayer platform for cell sheet engineering
A chemically detachable platform was developed based on PSS/PAH multilayer films built on a sacrificial precursor film, degradable under mild conditions through reduction of disulfide-containing polyelectrolytes. Growth of human fibroblasts on this platform promotes cell phenotype switch into contractile phenotype necessary for wound healing, which is maintained after cell sheet lift-off. The obtained cell sheets could be used as autologous explant.

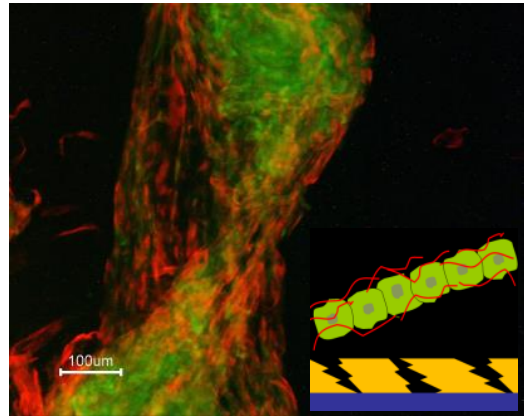




\section{Introduction}

Aimed at the maintenance and the recovery of native functions, cell sheet engineering is emerging as a promising approach to construct in vitro tissues or organs for transplantation into damaged host tissues. ${ }^{1 \text {, }}$ ${ }^{2}$ Different strategies of cell sheet detachment were successfully developed such as the use of thermoresponsive polymers, ${ }^{3-5}$ bioresorbable layers, ${ }^{6,7}$ enzymatic digestion of the substrate, ${ }^{8}$ magnetic force based $^{9}$ or electrochemical based detachment. ${ }^{10-12}$ However, versatile and mild methods for cell sheets development remain a challenge due to persisting drawbacks such as irrelevant control over gene expression induced by the detachment process. ${ }^{13}$ Enzymatic treatment may induce damage to cell membranes by hydrolyzing various membrane-associated proteins, resulting in impairment of cell functions. Strategies based on biodegradable polymers (such as polyglycolic acid, poly-L-lactic acid, polycaprolactone) provide promising results in vitro, but in vivo data revealed severe limitations, together with too fast degradation rates and promotion of acute inflammatory responses. ${ }^{14-16}$

Polyelectrolyte multilayer (PEMs) films, obtained by the alternate deposition of polycations and polyanions, emerged as a simple approach to modify surfaces in a controlled way. ${ }^{17,} 18$ Poly(allylamine hydrochloride) and poly(styrene sulfonate) (PAH/PSS) films constitute a good substrate for differentiated cell culture and then tissue engineering. ${ }^{19-25}$ Those films even accelerate the differentiation of circulating vascular progenitor cells, harvested from peripheral blood into mature and functional SMCs or ECs. ${ }^{26,} 27$ However, tissues formed from cells cultured on PSS/PAH films are difficult to harvest while preserving cell-cell junction and their deposited extracellular matrix (ECM) compounds. Liao et al. used thermoreponsive PEMs for an efficient removal of human mesenchymal stem cells ${ }^{28}$. Depending on the substrate on which PEM films were deposited, free standing films were lifted off using extreme acidic conditions for silica or silicon substrates, acetone for cellulose substrates, ${ }^{29}$ tetrahydrofuran or basic conditions for polystyrene substrates. ${ }^{30}$ Organic solvent and extreme $\mathrm{pH}$ are however incompatible with cell viability and cannot be used to detach cellular sheets grown on PEM platforms. Buck et al. reported the detachment of free standing thin films based on azalactone-containing polymer multilayers by immersion in mildly acidic aqueous environment. ${ }^{31}$ 
In this study, we describe a novel biocompatible and easily applicable chemical method for harvesting cell tissues in vitro. PSS/PAH multilayer films, that served as a substrate for the formation of cell layers, were built on a sacrificial precursor film. This sacrificial film, based on disulfide-containing polycation and polyanion, was degraded by a reducing agent under mild conditions, compatible with cell viability and phenotype stability. Cleavable disulfide bond under reductive conditions is widely accepted and has been applied to produce porous multilayer films, ${ }^{32}$ and in $\operatorname{drug}^{33-35}$ or gene delivery. ${ }^{36,37}$ Human gingival fibroblasts (HGFs) were used to produce cell sheets because they are an easy source of autologous primary cells with little donor-site morbidity. They are the main population in oral mucosa of nonmyocyte cells dedicated to establishment and maintenance of ECM and are useful graft materials for the regeneration of alveolar bone and periodontal ligaments. ${ }^{38}$ HGFs sheets have thus a potential use for in vivo wound healing due to HGFs ability to adopt a contractile phenotype during tissue remodeling.

\section{Results and discussion}

Characterization of Human Gingival Fibroblasts cell sheets cultured on PAH/PSS films. We first investigated the HGFs behavior on PAH/PSS multilayers compared to a glass substrate. Although the morphological observations of HGFs performed after 7 days of culture did not show any difference between (PAH/PSS) $)_{10}$-PAH films and glass substrate, the mitochondrial activity assessed by Alamar Blue $^{\mathrm{TM}}$ reagent showed a higher activity for cells cultivated on (PAH/PSS) ${ }_{10}-\mathrm{PAH}$ films (Figure S-1 in Supporting Information, SI). Cytoskeleton staining showed that HGFs cells are well spread and organized. Indeed, F-actin staining shows the presence of polymerized actin fibers lying parallel one to each other on both glass and PEMs substrate (Figure 1). The density of F-actin fibers seems higher on PAH/PSS films ended by PAH. All these results demonstrate a better proliferation of HGFs on PAH/PSS films compared to glass substrate. 

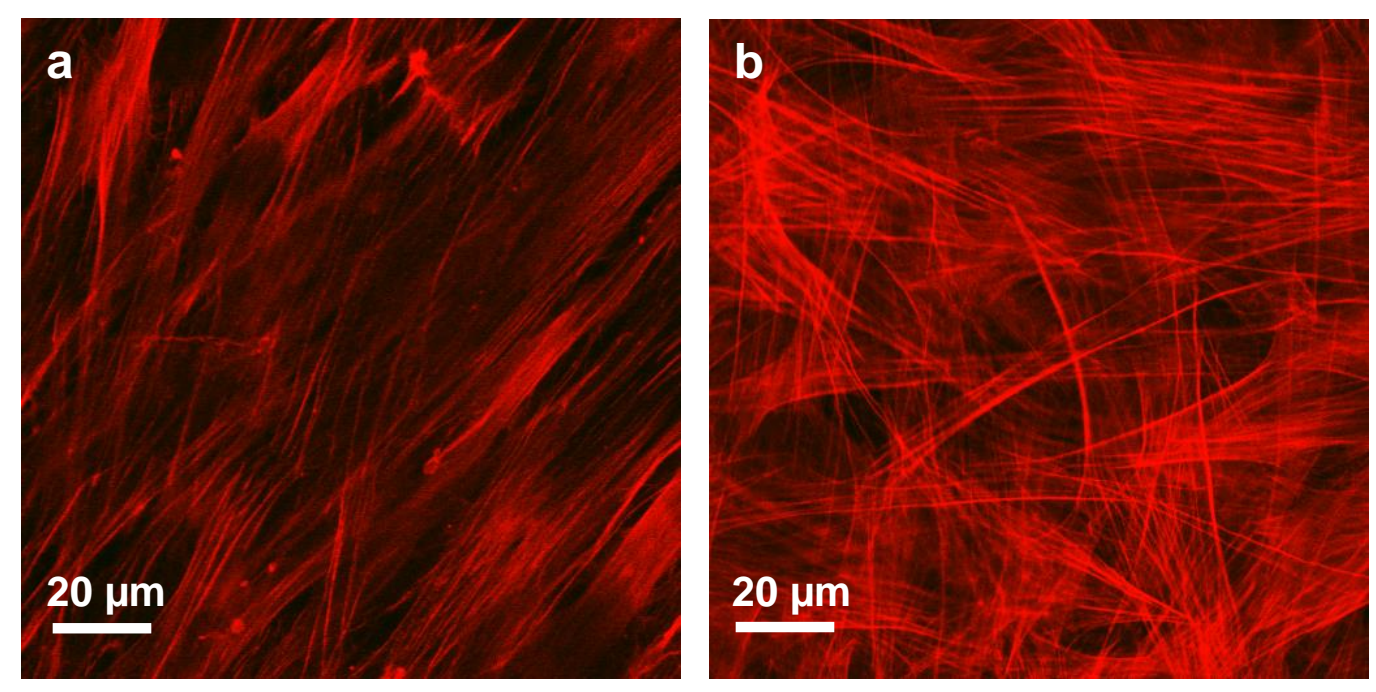

Figure 1: Cytoskeleton visualization of HGFs by F-actin filament stained with phalloidin® (red labelling) observed by confocal microscopy, after 14 days of culture on a (a) glass substrate and (b) (PAH/PSS) ${ }_{10}$-PAH film.

In vivo during wound healing and tissue remodeling, the fibroblasts acquire a contractile phenotype $\mathrm{e}^{39}$ by increasing the expression of contractile proteins such as alpha smooth muscle actin ( $\alpha-\mathrm{SMA})$. Recently, Berthelemy et al showed the high expression of this protein for progenitor cells cultivated on PAH/PSS films. ${ }^{27}$ The expression of contractile proteins of HGFs, seeded on glass and PSS/PAH films, has been checked at both gene and protein level. The $\alpha$-SMA gene, expressed by cells, was investigated by quantitative Real-time Polymerase Chain Reaction (qRT-PCR). These experiments included three housekeeping gene controls as internal references hypoxanthine phosphoribosyl transferase1 (HPRT1), beta-2 microglobulin (B2M) and glyceraldehyde phosphate dehydrogenase (GAPDH). HPRT1, related to nucleotide metabolism, is generally recognized to be independent on phenotype. B2M and GAPDH were selected for the stability of their expression during wound healing. ${ }^{40}$ Triplicate samples of cells, grown on glass and (PAH/PSS) 10 -PAH films, were analyzed after 5, 15 and 30 days of culture. Figure 2 shows, three to four times higher levels of $\alpha$-SMA mRNA for cells cultivated on PEMs in comparison to glass. PSS/PAH films dramatically promote the expression of $\alpha$-SMA gene related to the contractile protein. 


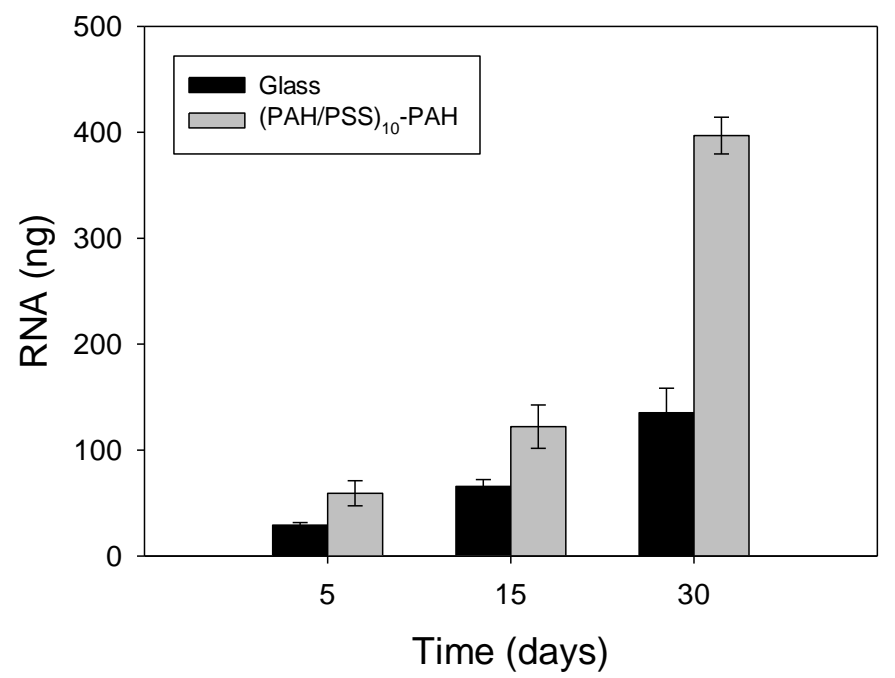

Figure 2: $\alpha$-SMA mRNA quantification of HGFs cultivated on glass substrate and (PAH/PSS $)_{10}-\mathrm{PAH}$ films during 5, 15 and 30 days.
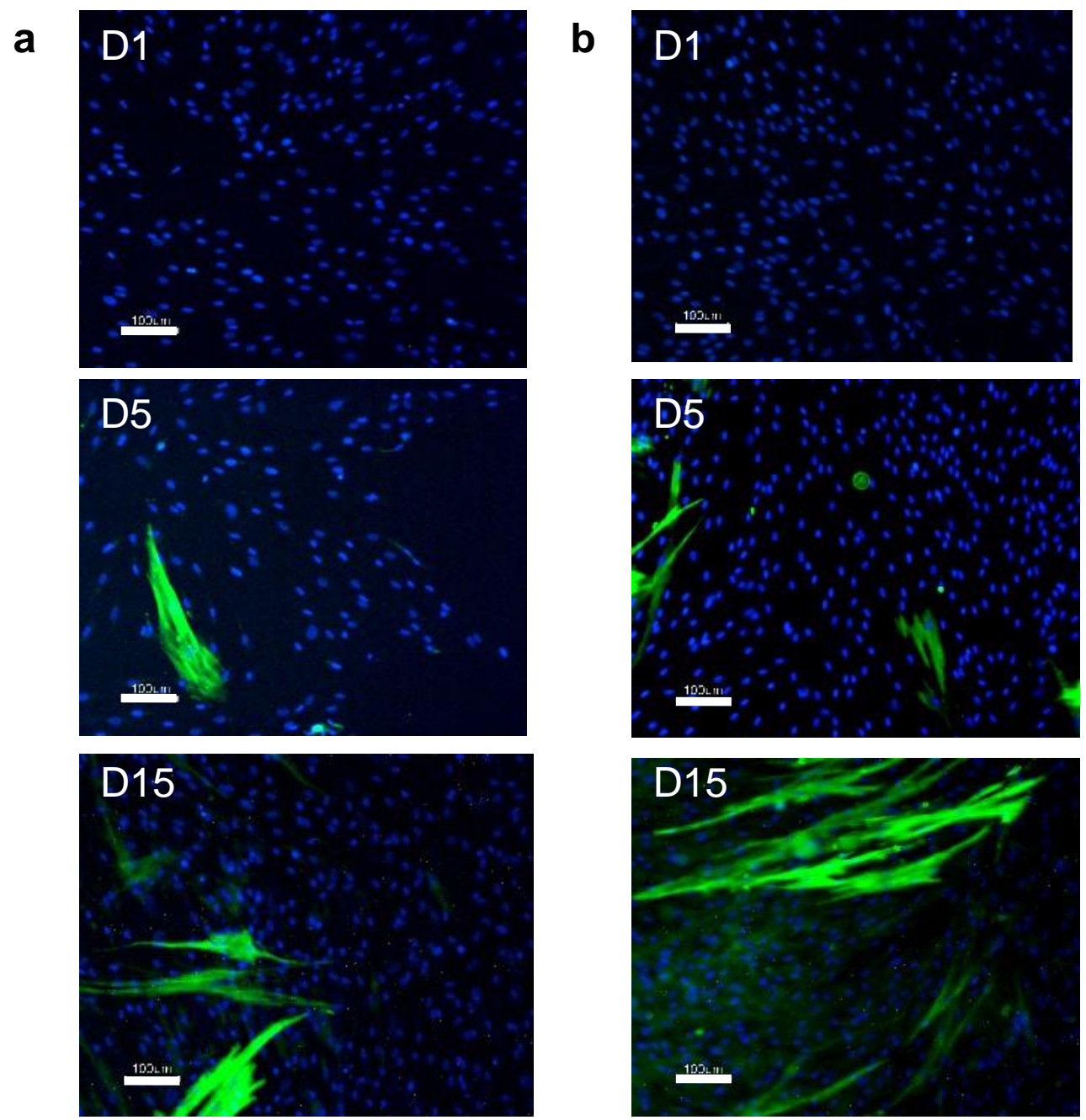

Figure 3: Detection of $\alpha$-SMA marker (green labeling) by immunochemistry and nuclei blue counterstaining of HGFs cultured (a) on glass substrate and (b) (PAH/PSS) ${ }_{10}$-PAH after 1, 5 and 15 days. The scale bars represent $100 \mu \mathrm{m}$. 
The expression of $\alpha$-SMA contractile protein was checked by immunocytochemistry staining. Almost all HGFs cultivated on PAH/PSS films were positive to $\alpha$-SMA marker after 15 days (Figure 3). Statistical analysis showed significant differences $(\mathrm{P}<0.001$ by Mann-Whitney test) in the number of HGFs acquiring contractile phenotype on PAH/PSS films compared to glass substrate from the fifth day of culture (Figure S-2 in SI). After 15 days, the number of HGFs with contractile phenotype are increased by about 36\% when cultured on PAH/PSS films compared to glass substrate (control: $201 \pm$ 25 per $\mathrm{mm}^{2}$; (PAH/PSS) $10-\mathrm{PAH}$ film: $273 \pm 33$ per $\mathrm{mm}^{2}$ ). The contractile phenotype of HGFs is more pronounced when seeded on PAH/PSS films compared to glass substrate. In addition to the expression of the contractile markers, tissue healing needs to have an appropriate ECM deposition. ${ }^{39}$ Then, the secretory activities of HGFs cultivated on PAH/PSS films were investigated by immunocytochemistry. At the beginning of wound healing, collagen I (COL1) is the main component of the extracellular matrix produced by fibroblasts. At the wound level, tissue homeostasis is controlled by proteolytic enzymes such as matrix metalloproteinase-2 (MMP-2). HGFs cultivated on PAH/PSS express both pro-COL1 and pro-MMP-2 proteins (Figure 4).
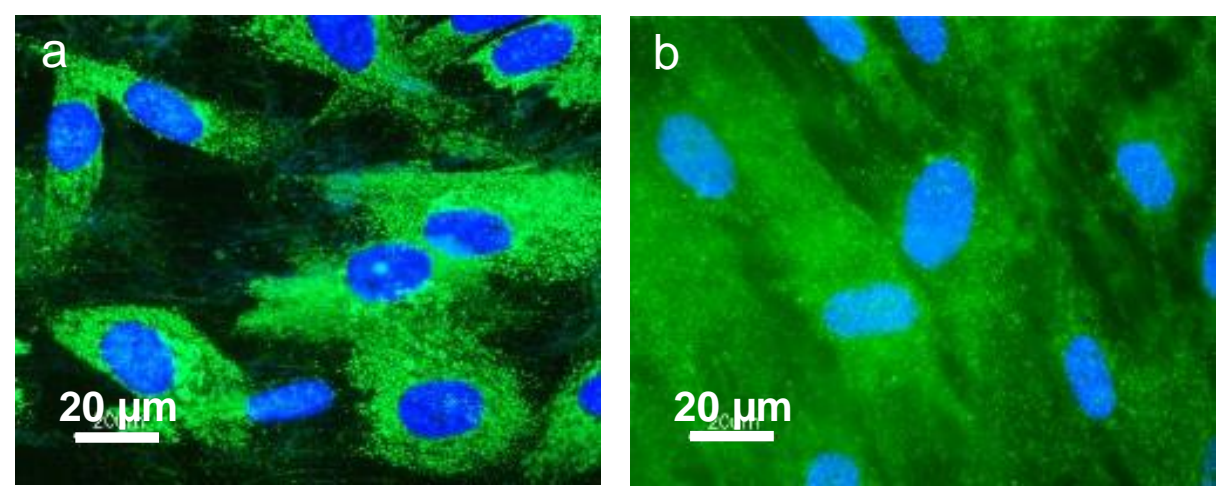

Figure 4: Detection of (a) pro-COL1 (green labelling) and (b) pro-MMP2 (green labelling) by immunochemistry and blue counterstaining of HGFs nuclei after 15 days culture on (PAH/PSS) $10-\mathrm{PAH}$ film.

These results confirm an advantage for PAH/PSS films in terms of fibroblast functionality (contractility and homeostasis properties). These properties are essential for connective tissue remodeling during normal wound healing. ${ }^{41}$ Production of cell sheets expressing an accurate phenotype would be of interest as substrate for tissue repair. 
Buildup and degradation of disulfide containing polyelectrolyte films. PAH/PSS films ended by PAH have been shown to be appropriated films for HGFs cells culture and even suitable platforms for cells sheet engineering. In order to detach the HGFs cell layer obtained on PAH/PSS films, we synthesized by polymerization cleavable polyanion (poly(vinyl benzoic acid, $\mathrm{PVBACOO}^{-}$) and polycation (polycationic derived of poly(vinyl benzoic acid), $\mathrm{PVBANH}_{3}{ }^{+}$) (Figure 5). Both polymer backbones include disulfide bonds that can be reduced by tris(2-carboxyethyl)phosphine (TCEP). They are thus cleavable into small molecular fragments. Those polyelectrolytes, soluble in water, were used to build a sacrificial film on which a capping PAH/PSS film was deposited in order to detach it later on by contact with TCEP.
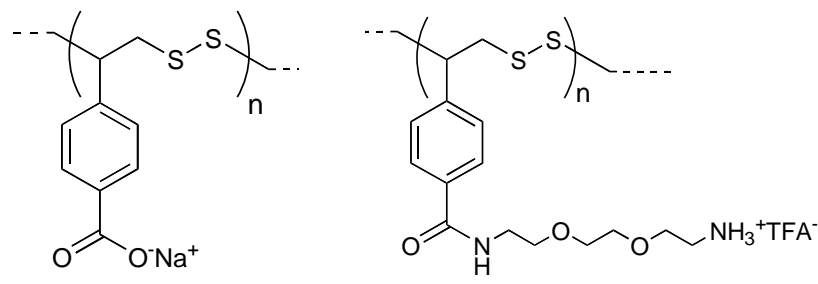

PVBACOO-

PVBANH $_{3}{ }^{+}$

Figure 5: Chemical formulas of cleavable polyelectrolytes $\mathrm{PVBACOO}^{-}$and $\mathrm{PVBANH}_{3}{ }^{+}$
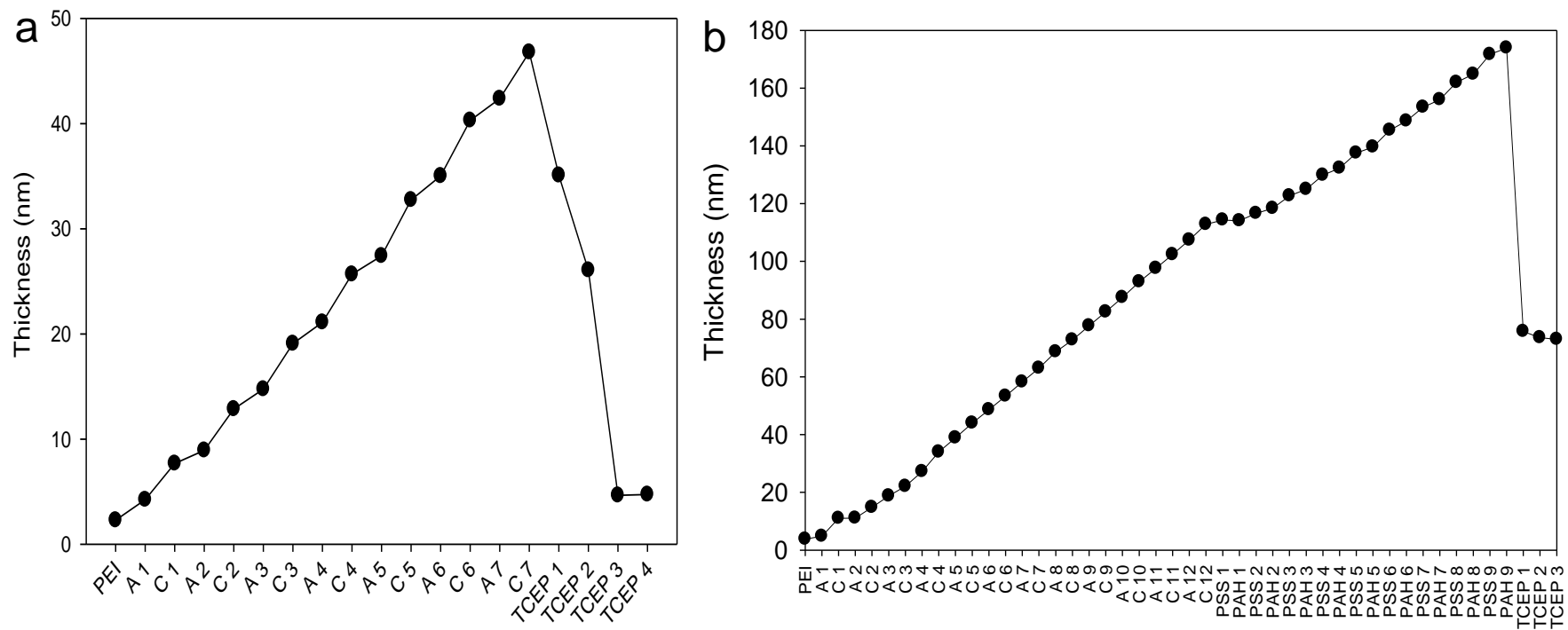

Figure 6: Thickness evolution of (a) PEI-(PVBACOO $\left./ \mathrm{PVBANH}_{3}{ }^{+}\right)_{7}$ and (b) PEI-(PVBACOO $\left./ \mathrm{PVBANH}_{3}{ }^{+}\right)_{12}-(\mathrm{PSS} / \mathrm{PAH})_{9}$ multilayer films, determined by QCM, as a function of the last layer deposited, followed by four injections of $5 \mathrm{mM}$ TCEP solution. $A$ represents the polyanion $\mathrm{PVBACOO}^{-}$ and $B$ represents the polycation $\mathrm{PVBANH}_{3}{ }^{+}$. 
$\mathrm{PVBACOO}^{-} / \mathrm{PVBANH}_{3}{ }^{+}$multilayer films, built in physiological conditions $(150 \mathrm{mM} \mathrm{NaCl}, \mathrm{pH} 7.4)$, grows linearly with the number of deposited layers (Figure 6a). After contact with $3 \mathrm{~mL}$ of TCEP solution at $5 \mathrm{mM}$ by three successive injections, the film is dissolved at $96 \%$ in thickness. In the case of PEI-(PVBACOO $\left./ \mathrm{PVBANH}_{3}{ }^{+}\right)_{12}-(\mathrm{PSS} / \mathrm{PAH})_{9}$ films, the contact with TCEP leads to the degradation of $60 \%$ in film thickness (Figure 6b). Atomic force microscopy (AFM) was used to monitor the topography and the thickness of $\mathrm{PVBACOO}^{-} / \mathrm{PVBANH}_{3}{ }^{+}$films with and without the capping PAH/PSS film. As shown in Figure 7a, the PEI-(PVBACOO$\left./ \mathrm{PVBANH}_{3}{ }^{+}\right)_{10}$ film is homogeneous and shows a roughness of $8 \mathrm{~nm}$ (Figure S-3a in SI). After 30 minutes of contact with TCEP, the film remained homogenous (Figure S-3b) with a roughness of $3 \mathrm{~nm}$ but its dry thickness decreased from 32 to $5 \mathrm{~nm}$ (Figure $7 \mathrm{~b}$ ). Chen et al. ${ }^{32}$ showed the formation of pores on multilayered thin films containing a blend of reducible polycations, based on cleavable disulfide bonds. In this work, a non-reducible polyanion was employed. No pore formation was observed in our system which is composed of both reducible polycations and polyanions. TCEP treatment leads to almost complete film dissolution. When a capped $\mathrm{PAH} / \mathrm{PSS}$ film is built on top of $\mathrm{PVBACOO}^{-} / \mathrm{PVBANH}_{3}{ }^{+}$, an homogeneous film is obtained with a higher roughness, about $14 \mathrm{~nm}$ compared to the $3 \mathrm{~nm}$ of the non-capped film (Figure S-3c in SI). TCEP treatment of the PEI-(PVBACOO$\left.-/ \mathrm{PVBANH}_{3}{ }^{+}\right)_{10}-(\mathrm{PSS} / \mathrm{PAH})_{10}$ film induced an homogeneous decrease of the dry thickness from 58 à $30 \mathrm{~nm}$ with almost no change in roughness (Figure 7c and 7d, Figure S$3 \mathrm{~d}$ in SI). Finally, the $\left(\mathrm{PVBANH}_{3}{ }^{+} \mathrm{PVBACOO}^{-}\right)_{10}-(\mathrm{PAH} / \mathrm{PSS}-\mathrm{Rhodamine})_{10}-\mathrm{PAH}$ architecture was built and incubated during $10 \mathrm{~min}$ in $5 \mathrm{mM}$ TCEP solution. Fluorescent microscopy images confirmed the delamination of the PEM and the presence of PSS-Rhodamine on the released membrane after TCEP treatment (Figure S-4 in SI). 
a
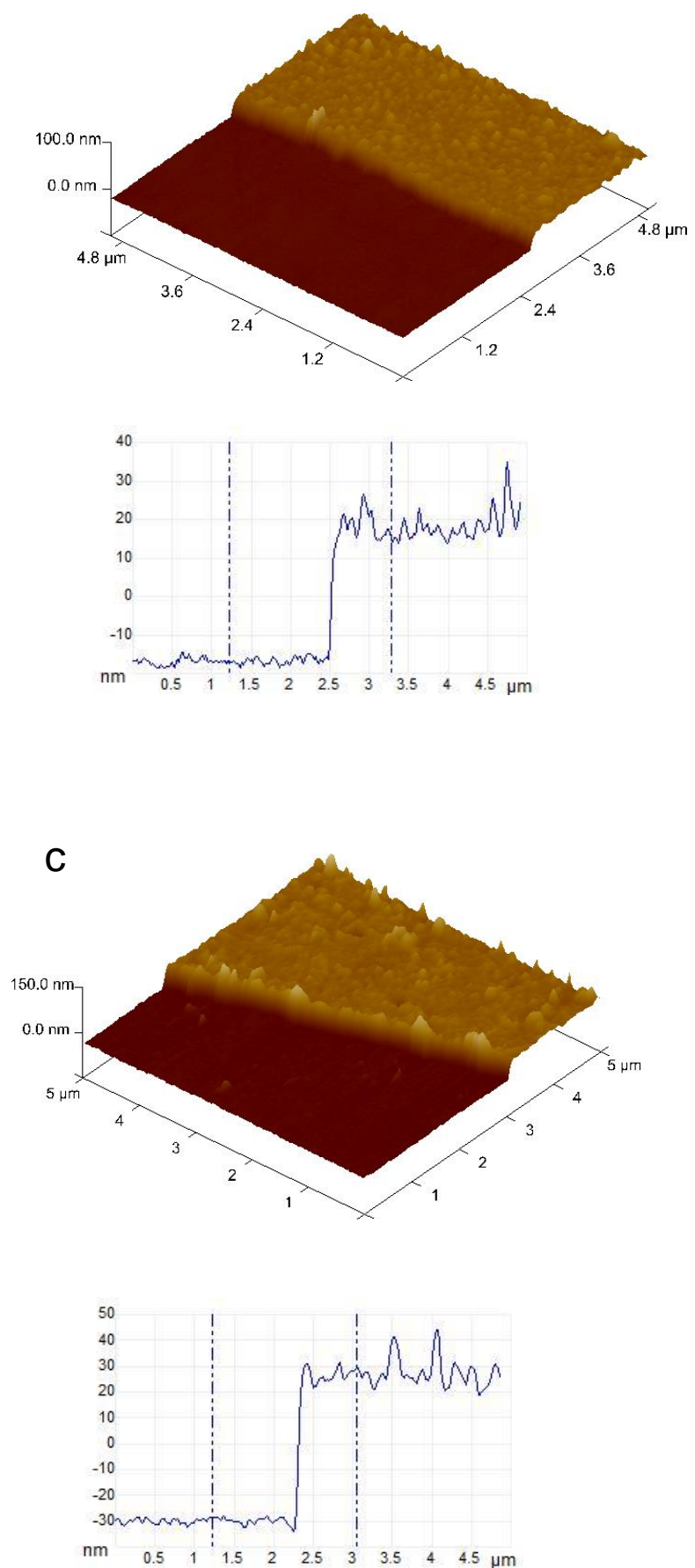

b
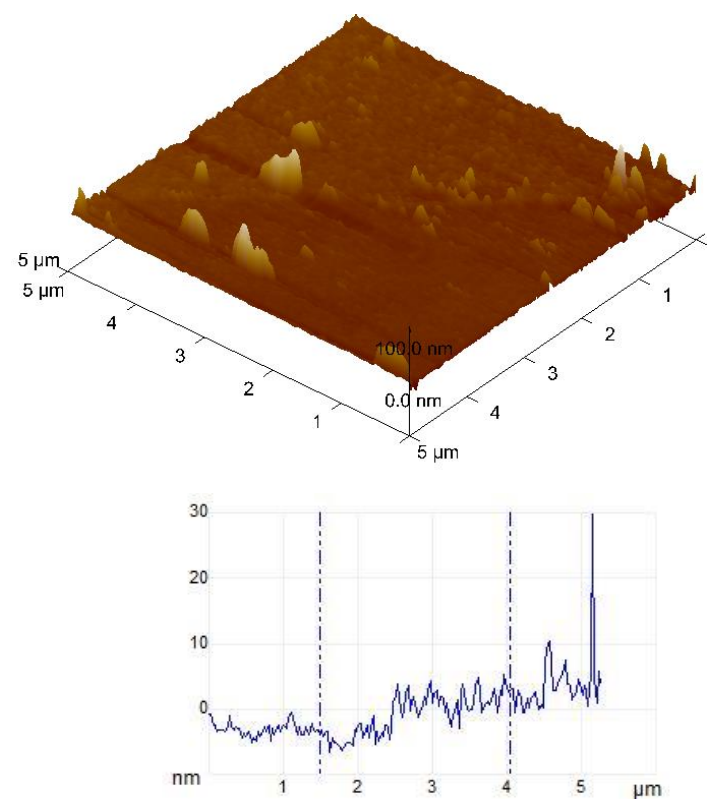

d
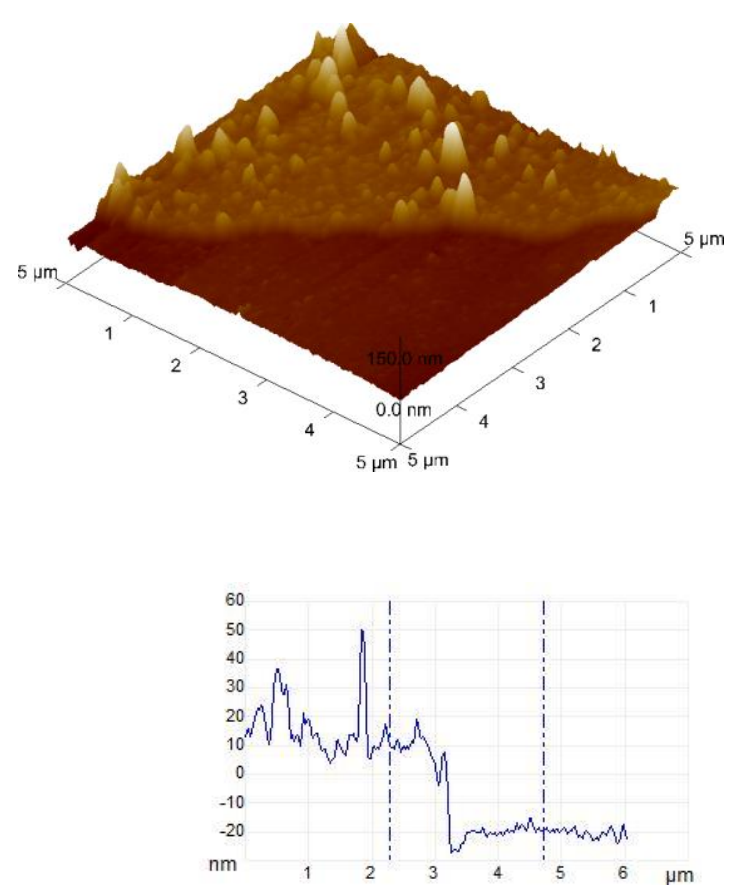

Figure 7: Typical AFM 3D images, obtained in contact mode in dry state, of PEI-(PVBACOO$\left./ \mathrm{PVBANH}_{3}{ }^{+}\right)_{10}$ film (a) before and (b) after TCEP treatment $(5 \mathrm{mM}, 30 \mathrm{~min})$ and of PEI-(PVBACOO$\left./ \mathrm{PVBANH}_{3}{ }^{+}\right)_{10}-(\mathrm{PSS} / \mathrm{PAH})_{10}$ film (c) before and (d) after TCEP treatment $(5 \mathrm{mM}, 30 \mathrm{~min})$. The films were scratched before observation. 
Detachment of cell sheet and cell phenotype characterization. HGFs viability remains similar for PSS/PAH films built either directly on the glass substrate or on a $\mathrm{PVBANH}_{3}{ }^{+} / \mathrm{PVBACOO}^{-}$sacrificial platform (Figure S-1 in SI). To test the cytotoxicity of the reductive agent, HGFs previously cultured on glass substrate during 7 days were incubated with a $5 \mathrm{mM}$ TCEP solution (Figure S-5 in SI). TCEP solution does not show any cytotoxicity to HGFs up to 30 minutes of contact.
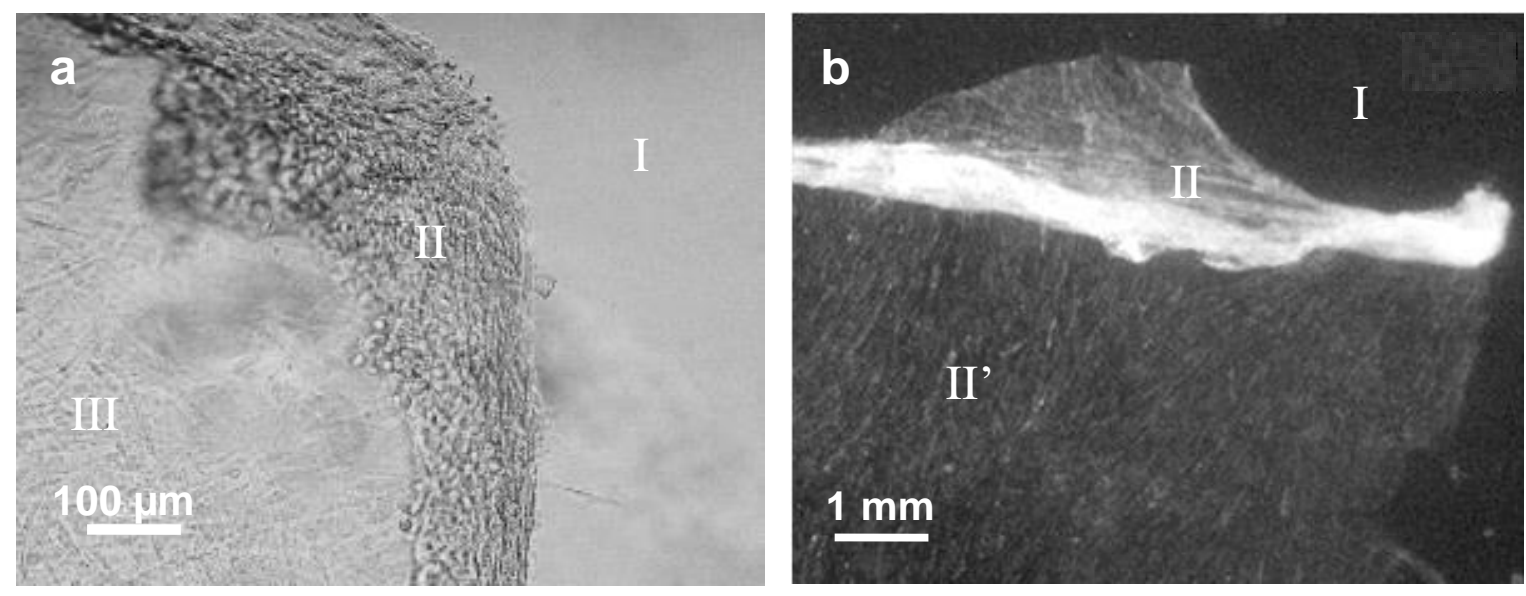

Figure 8. Images obtained by optical (a) microscopy and (b) macroscopy of a HGFs cell sheet, cultured for 30 days on a $\left(\mathrm{PVBANH}_{3}{ }^{+} / \mathrm{PVBACOO}^{-}\right)_{10}-(\mathrm{PAH} / \mathrm{PSS})_{10}-\mathrm{PAH}$ film, recovered from mild chemical treatment during $30 \mathrm{~min}$ : the areas represent respectively (I) the glass substrate, (II) and (II') free standing HGFs cell sheet and (III) HGFs cell layer.

After 30 days of culture on $\left(\mathrm{PVBANH}_{3}{ }^{+} / \mathrm{PVBACOO}^{-}\right)_{10}-(\mathrm{PAH} / \mathrm{PSS})_{10}-\mathrm{PAH}, \mathrm{HGFs}$ cell layers were incubated with $5 \mathrm{mM}$ TCEP for less than $30 \mathrm{~min}$. At the beginning of the process, the detached part of the HGFs cell sheets (II) remained connected to the cell layer (III) that still adhered to the surface (Figure 8a). Figure 8b shows a macroscopic image of the obtained free standing cell sheet (II') after total detachment. HGFs sheets were then characterized by immunochemical detection of COL1 and $\alpha-$ SMA. Immunostaining revealed the preservation of secreted pro-COL1 and $\alpha$-SMA expression suggesting that TCEP treatment had no effect on HGF tissue integrity (Figure 9). 

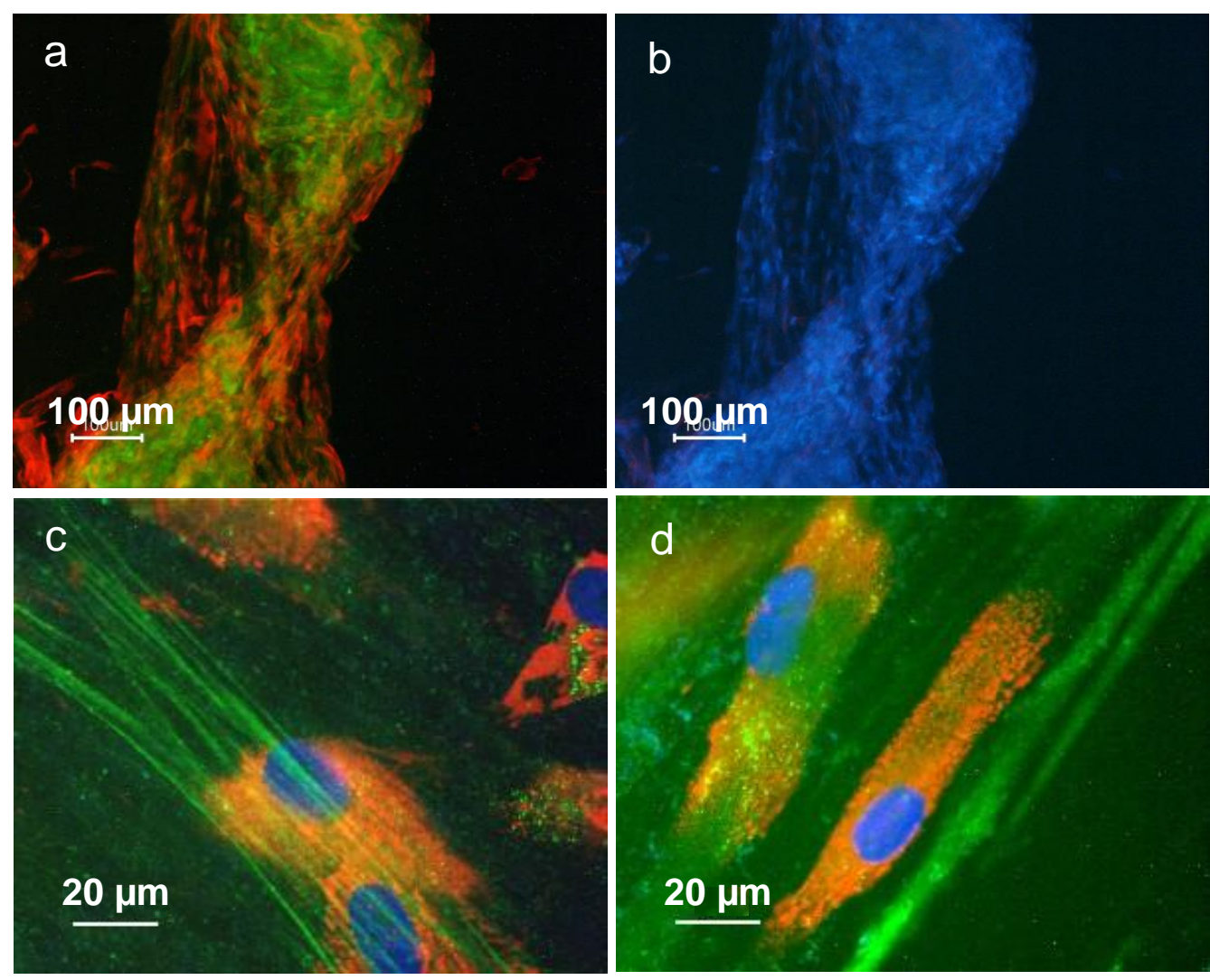

Figure 9: Detection of pro-COL1 (red labeling) and $\alpha$-SMA (green labeling) markers by immunochemistry and blue counterstaining of HGFs nuclei after 30 days culture on a $\left(\text { PVBANH }_{3}+\text { PVBACOO- }\right)_{10}$-(PAH/PSS) $10-\mathrm{PAH}$ film after detachment (a, b and d) and (c) before detachment of the cell sheet.

A $\left(\mathrm{PVBANH}_{3}{ }^{+} / \mathrm{PVBACOO}^{-}\right)_{10}-(\mathrm{PAH} / \mathrm{PSS}-\mathrm{Rhodamine})_{10}-\mathrm{PAH}$ film was also used as a substrate for HGFs culture for 30 days and underwent the TCEP treatment. Figure S-6 in SI shows the presence of PSS-Rhodamine in the detached cell sheet showing the integrity of PAH/PSS film. PAH/PSS films constitute a good substrate for differentiated cell culture ${ }^{19-25}$ but also for the differentiation of stem cells into mature and functional SMCs or ECs. ${ }^{26,27}$ Recently, Guillaume-Gentil et al. ${ }^{42}$ report the use of PAH/PSS thin films as substrate for the growth and subsequent release under electrochemical control of mesenchymal stem cell sheets that keep their mesodermal plasticity. These studies and our results show a good biocompatibility of PSS/PAH films.

Cell migration is an important characteristic for tissue healing. According to the explants technique, we have seeded fragments of detached cell sheet on a new glass substrate. After 30 days of HGFs culture (Figure 10a) and detachment, fragments of the detached cell sheet were put in culture to check the 
compatibility of the detachment procedure (Figure 10b). As soon as three days of culture, cells migrated from the cell sheet fragment (I) to the glass substrate. After 10 days of culture, outgrowth of cells from the cell sheet fragments was observed with retention of the typical spindle-shape of differentiated cells (Figure 10c and 10d). These results demonstrate that the detached cells kept their migration property.
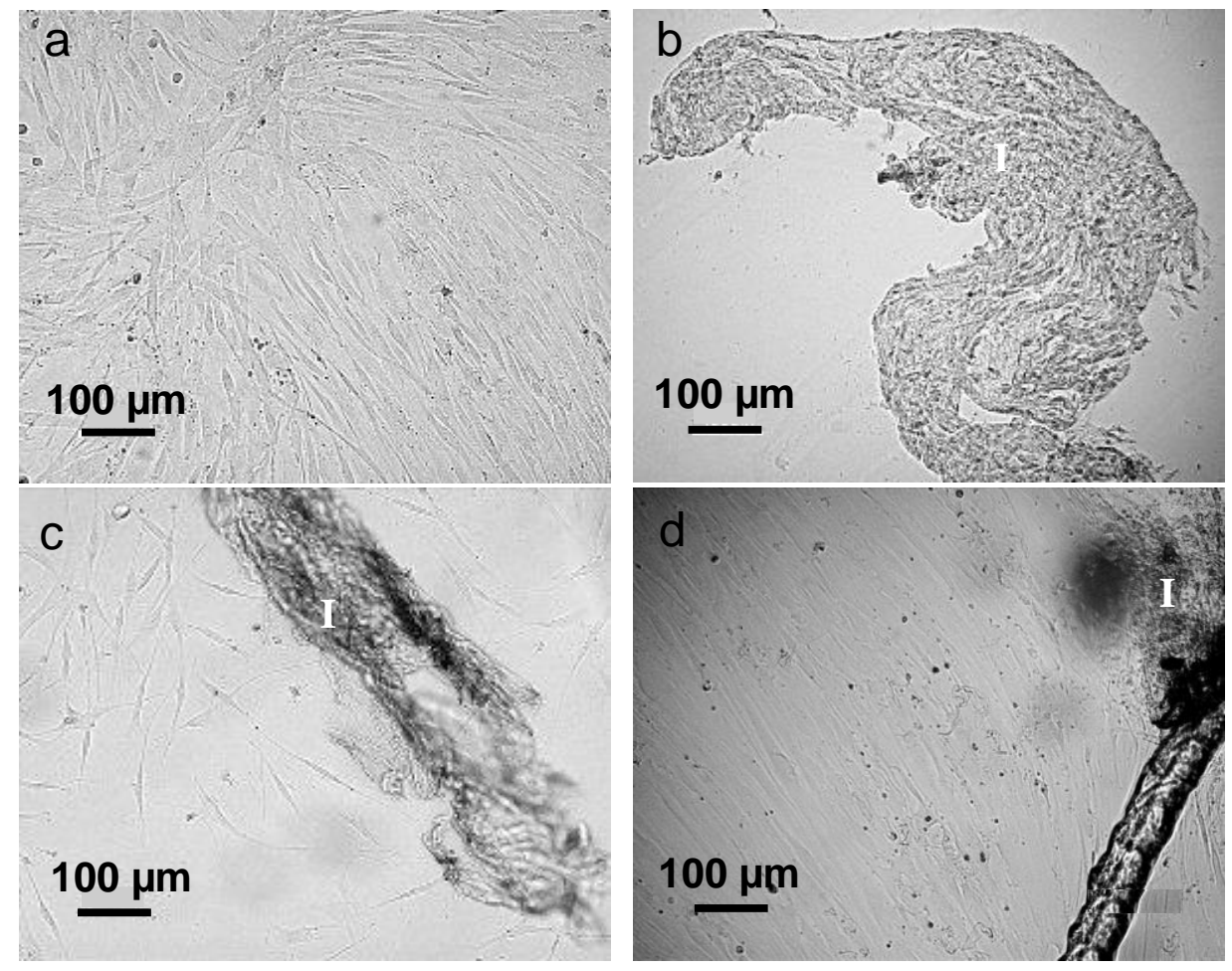

Figure 10: Phase contrast microscopy images of HGFs cell sheet after 15 days of culture on a $\left(\mathrm{PVBANH}_{3}{ }^{+} / \mathrm{PVBACOO}^{-}\right)_{10}-(\mathrm{PAH} / \mathrm{PSS})_{10}-\mathrm{PAH}$ film (a) before detachment, (b) detached and transferred on a new substrate, (c) after 3 days of culture and (d) after 10 days of culture. (I) represents the initially detached cell sheet.

A major advantage of this chemically detachable platform, based on PEMs, concerns the ability to be equipped by an additional multiple functionalization with growth factors that could be necessary to engineer specific demanding cell phenotypes. Moreover, the use of a chemically degradable platform does not need dedicated apparatus as electrochemical or magnetic force apparatus.

\section{Conclusion}


In this work, we describe a platform to produce detachable human autologous cell sheets. The obtained results demonstrate the ability of the platform not only to drive HGFs adhesion and proliferation but also to change their morphology to spread and express activation-dependent phenotypes. Specifically, $\left(\mathrm{PVBANH}_{3}{ }^{+} / \mathrm{PVBACOO}^{-}\right)_{10}-(\mathrm{PAH} / \mathrm{PSS})_{10}-\mathrm{PAH}$ platform promotes HGFs conversion to the contractile phenotype, which is maintained after cell sheet lift-off. In this respect, the method could provide fibroblast-seeded substrates having the potential to reorganize ECM and thereby to confer adaptation to tissue injury. As such, the construct described here could be envisioned as substrate for tissue repair. It could also serve a synthetic cell platform for research on connective tissue disease and evaluation of novel therapeutic agents.

Ackowledgments : The authors acknowledge financial supports from ANR E-DETACHPEM BLAN08-1_315174, ANR SUBVACEL ANR-07-TECSAN-022-01 and CNRS Prise de risque 2008 (Projet Vaisseau In situ) grants.

\section{Experimental section}

Synthesis of polymers. Thin layer chromatography (TLC) was performed on precoated plates $(0.25 \mathrm{~mm}$ Silica Gel 60, F254, Merck, Darmstadt, Germany). Products were purified by chromatography over silica gel (Silica Gel 60, 40-63 m, Merck, Darmstadt, Germany). NMR spectra were recorded on Bruker 300 $\mathrm{MHz}$ Avance DPX and $400 \mathrm{MHz}$ Avance 3 ultrashield+ instruments. ${ }^{1} \mathrm{H}-,{ }^{13} \mathrm{C}-\mathrm{NMR}$ chemical shifts $\delta$ are reported in ppm relative to their standard reference $\left({ }^{1} \mathrm{H}: \mathrm{CHCl}_{3}\right.$ at $7.27 \mathrm{ppm}, \mathrm{DMF}\left(-\mathrm{CH}_{3}\right)$ at $2.88 \mathrm{ppm}$, tert-butanol at $1.24 \mathrm{ppm} ;{ }^{13} \mathrm{C}: \mathrm{CDCl}_{3}$ at $77.0 \mathrm{ppm}$ ). Mass Spectra (MS) were recorded on an Agilent MSD SQ 1200SL instrument, using multimode APCI / Electrospray (ESI) mode and coupled to HPLC 1200SL. Mass data are reported in mass units $(\mathrm{m} / \mathrm{z})$. Unless otherwise specified, all chemicals were reagent grade and were used as received: sulfur flowers and 4-vinylbenzoic acid were purchased from Alfa Aesar (Bischeim, France) sodium sulfide, N-hydroxysuccinimide, N-Boc-2,2'(ethylenedioxy)diethylamine were all purchased from Aldrich (St. Quentin Fallavier, France), N,N'dicyclohexyl-carbodiimide was purchased from Acros (Thermo Fisher Scientific, Strasbourg, France).

Synthesis of BVBA. A solution of bromine $(360 \mu \mathrm{L}, 6.95 \mathrm{mmol})$ in chloroform $(5 \mathrm{~mL})$ was added dropwise at $0^{\circ} \mathrm{C}$ to a solution of vinylbenzoic acid (VBA) $(1 \mathrm{~g}, 6.74 \mathrm{mmol})$ in chloroform $(20 \mathrm{~mL})$. The solution was strirred at room temperature for 4 hours. Chloroform was removed under vacuum to give $2.05 \mathrm{~g}(98 \%)$ of BVBA as a white solid. ${ }^{1} \mathrm{H} \mathrm{NMR}\left(300 \mathrm{MHz}, \mathrm{CDCl}_{3}\right) \delta 4.05\left(\mathrm{~m}, 2 \mathrm{H}, \mathrm{CH}_{2}\right), 5.16(\mathrm{dd}, J=$ $5.2,11.0 \mathrm{~Hz}, 1 \mathrm{H}, \mathrm{CHBr}), 7.52\left(\mathrm{~d}, J=8.4 \mathrm{~Hz}, 2 \mathrm{H}, \mathrm{CH}_{\mathrm{Ar}}\right), 8.13\left(\mathrm{~d}, J=8.4 \mathrm{~Hz}, 2 \mathrm{H}, \mathrm{CH}_{\mathrm{Ar}}\right),{ }^{13} \mathrm{C} \mathrm{NMR}(100$ $\left.\mathrm{MHz}_{\mathrm{CDCl}}\right) \delta 34.43\left(\mathrm{CH}_{2}\right), 49.30(\mathrm{CHBr}), 128.14\left(\mathrm{CH}_{\mathrm{Ar}}\right), 130.06\left(\mathrm{C}_{\mathrm{Ar}} \mathrm{CHBr}\right), 130.98\left(\mathrm{CH}_{\mathrm{Ar}}\right), 144.56$ $\left(\mathrm{C}_{\mathrm{Ar}} \mathrm{COOH}\right)$.

Synthesis of Polymer PVBACOO-. A solution of sulfur flowers $(114 \mathrm{mg}, 3.57 \mathrm{mmol})$ and sodium sulfide $(278 \mathrm{mg}, 3.57 \mathrm{mmol})$ in water $(10 \mathrm{~mL})$ was stirred 2 hours at $70^{\circ} \mathrm{C}$. Then a solution of BVBA $(1.1 \mathrm{~g}$, $3.57 \mathrm{mmol})$ and sodium hydroxide $(143 \mathrm{mg}, 3.57 \mathrm{mmol})$ in water $(10 \mathrm{~mL})$ was added. The mixture was 
stirred at room temperature for 24 hours. The polymer was precipited in ethanol to give $500 \mathrm{mg}$ as a white solid. ${ }^{1} \mathrm{H}$ NMR $\left(300 \mathrm{MHz}, \mathrm{D}_{2} \mathrm{O}\right.$, reference tert-butanol) $\delta$ 2.5-4.5 (m, 3nH, $\left.\mathrm{CHCH}_{2}\right), 7.27(\mathrm{~m}$, $\left.2 n \mathrm{H}, \mathrm{CH}_{\mathrm{Ar}}\right), 7.87\left(\mathrm{~m}, 2 n \mathrm{H}, \mathrm{CH}_{\mathrm{Ar}}\right) . n$ is the degree of polymerisation (DPn). PVBACOO ${ }^{-}$has a mean molecular weight of $\mathrm{Mw}=28 \times 103 \mathrm{~g} / \mathrm{mol}$ and a polydispersity $\mathrm{Mw} / \mathrm{Mn}=1.69$, determined by Steric Exclusion Chromatograpy - Multi Angle Light Scattering (SEC-MALS).

Synthesis of BVBANHBoc. To a solution of BVBA (872 mg, $2.83 \mathrm{mmol})$ in dichloromethane (40 mL), N,N'-dicyclohexylcarbodiimide (636 mg, $3.084 \mathrm{mmol}$ ) and N-hydroxysuccinimide (354 mg, 3.084 mmol) were added and stirred at room temperature for 30 minutes. A solution of N-Boc-2,2'(ethylenedioxy)diethylamine $(656 \mathrm{mg}, 2.83 \mathrm{mmol})$ in dichloromethane $(10 \mathrm{~mL})$ was added dropwise and kept under stirring at room temperature for 15 hours. After removing the precipitate, the residue was purified by silica-gel chromatography to afford $544 \mathrm{mg}(40 \%)$ of BVBANHBoc as a colorless oil. ${ }^{1} \mathrm{H}$ NMR (300 MHz, $\left.\mathrm{CDCl}_{3}\right) \delta 1.44\left(\mathrm{~s}, 9 \mathrm{H}, \mathrm{C}\left(\mathrm{CH}_{3}\right)_{3}\right), 3.29\left(\mathrm{~m}, 2 \mathrm{H}, \mathrm{CH}_{2} \mathrm{NHBoc}\right), 3.53-3.72\left(\mathrm{~m}, 10 \mathrm{H}, \mathrm{CH}_{2}\right.$ PEG), 3.97-4.09 (m, 2H, $\left.\mathrm{CH}_{2} \mathrm{Br}\right), 4.98(\mathrm{NH}), 5.14$ (dd, J = 5.2, $\left.10.7 \mathrm{~Hz}, 1 \mathrm{H}, \mathrm{CHBr}\right), 6.77(\mathrm{NH}), 7.47$ $\left(\mathrm{m}, 2 \mathrm{H}, \mathrm{CH}_{\mathrm{Ar}}\right), 7.81\left(\mathrm{~m}, 2 \mathrm{H}, \mathrm{CH}_{\mathrm{Ar}}\right),{ }^{13} \mathrm{C} \mathrm{NMR}\left(100 \mathrm{MHz}, \mathrm{CDCl}_{3}\right) \delta 28.9\left(\left(\mathrm{CH}_{3}\right)_{3}\right), 34.9\left(\mathrm{CH}_{2} \mathrm{Br}\right), 39.8-$ $40.3\left(\mathrm{NHCH}_{2}\right.$ and $\left.\mathrm{CH}_{2} \mathrm{NH}\right), 49.8(\mathrm{CHBr}), 70.6\left(\mathrm{CH}_{2} \mathrm{PEG}\right), 127.8-128.1\left(\mathrm{CH}_{\mathrm{Ar}}\right), 135.1\left(\mathrm{C}_{\mathrm{Ar}} \mathrm{CHBr}\right), 141.9$ $\left(\mathrm{C}_{\mathrm{Ar}} \mathrm{COOH}\right), 156.1$ and $167.0(\mathrm{CO}), \mathrm{LR}-\mathrm{MS}(\mathrm{ESI})$ calcd for $\mathrm{C}_{20} \mathrm{H}_{30} \mathrm{Br}_{2} \mathrm{~N}_{2} \mathrm{NaO}_{5}\left[(\mathrm{M}+\mathrm{Na})^{+}\right]$: 561.0399 ; found 561.0419 .

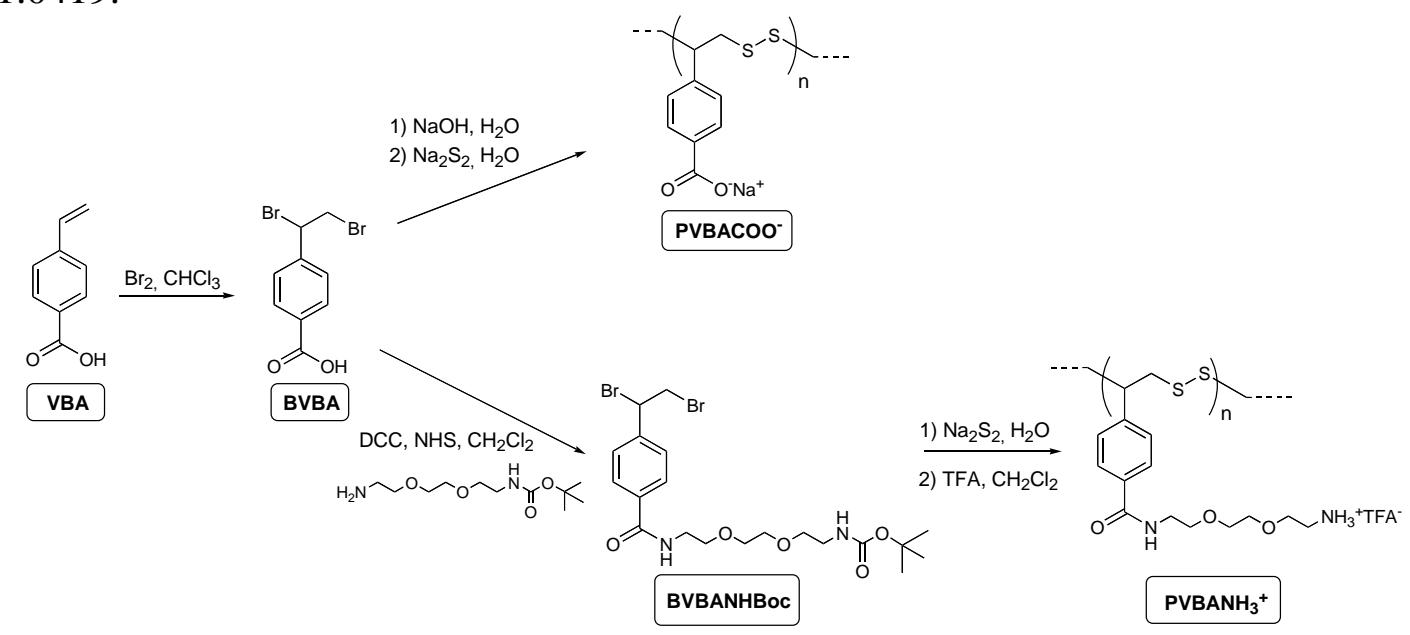

Scheme 2: Schematic representation of synthesis of polymer $\mathrm{PVBACOO}^{-}$and $\mathrm{PVBANH}_{3}{ }^{+}$

Synthesis of polymer PVBANHBoc. A solution of sulfur flowers (32 mg, $1.00 \mathrm{mmol}$ ) and sodium sulfide $(78 \mathrm{mg}, 1.00 \mathrm{mmol})$ in water $(6 \mathrm{~mL})$ was stirred 2 hours at $70^{\circ} \mathrm{C}$. The reaction mixture was added dropwise to a solution of BVBANHBoc $(540 \mathrm{mg}, 1.034 \mathrm{mmol})$ in DMF $(10 \mathrm{~mL})$. The solution was strirred at room temperature for 24 hours. The solution was diluted in ethanol $(20 \mathrm{~mL})$ and the polymer was precipited into chilled diethyl ether $(500 \mathrm{~mL})$ to give $264 \mathrm{mg}(64 \%)$ of the polymer PVBANHBoc as white a solid. ${ }^{1} \mathrm{H}$ NMR $\left(300 \mathrm{MHz}, \mathrm{D}_{2} \mathrm{O}\right.$, reference DMF) $\delta 1.30-1.38\left(\mathrm{~m}, 9 n \mathrm{H}, \mathrm{C}\left(\mathrm{CH}_{3}\right)_{3}\right), 3-3.81(\mathrm{~m}$, $\left.15 n \mathrm{H}, \mathrm{CH}_{2} \mathrm{PEG}, \mathrm{CHCH}_{2} \mathrm{~S}\right), 7.19-7.92\left(\mathrm{~m}, 4 n \mathrm{H}, \mathrm{CH}_{\mathrm{Ar}}\right) . n$ is the degree of polymerisation (DP $n$ ).

Synthesis of polymer PVBANH ${ }_{3}^{+}$. To a solution of polymer PVBANHBoc $(260 \mathrm{mg}, 0.64 \mathrm{mmol})$ in dichloromethane $(20 \mathrm{~mL})$, trifluoroacetic acid $(10 \mathrm{~mL})$ was added and stirred at room temperature for 24 hours. The solvent was removed by vacuum, water $(20 \mathrm{~mL})$ was added to dissolve the polymer. After filtration and lyophilization, the polymer $\mathrm{PVBANH}_{3}{ }^{+}$was allowed as a slightly green solid, $290 \mathrm{mg}$ (100\%). ${ }^{1} \mathrm{H}$ NMR $\left(300 \mathrm{MHz}, \mathrm{D}_{2} \mathrm{O}\right.$, reference tert-butanol) $\delta 3.13\left(\mathrm{~s}, 2 n \mathrm{H},-\mathrm{CH}_{2} \mathrm{NH}_{2}\right), 3.57(\mathrm{~m}, 10 n \mathrm{H}$, $\left.\mathrm{CH}_{2} \mathrm{PEG}\right), 2.7-4.5\left(\mathrm{bm}, 3 n \mathrm{H}, \mathrm{CHCH}_{2} \mathrm{~S}\right), 7.25\left(\mathrm{bm}, 2 n \mathrm{H}, \mathrm{CH}_{\mathrm{Ar}}\right), 7.75\left(\mathrm{bm}, 2 n \mathrm{H}, \mathrm{CH}_{\mathrm{Ar}}\right), n$ is the degree of polymerisation (DPn).

Chemicals and polyelectrolyte solutions. Poly(allylamine hydrochloride) $\left(\mathrm{PAH}, \mathrm{Mw}=7 \times 10^{4} \mathrm{~g} / \mathrm{mol}\right)$, 
Poly(sodium 4-styrenesulfonate) (PSS, Mw = $7.0 \times 10^{4} \mathrm{~g} / \mathrm{mol}$ ), poly(ethylene imine) (PEI, Mw= $75 \times$ $\left.10^{4} \mathrm{~g} / \mathrm{mol}\right)$, (4-(2-hydroxyethyl)-1-piperazine ethanesulfonic acid (Hepes) and Tris(2carboxyethyl)phosphine hydrochloride (TCEP) were all purchased from Sigma (St. Quentin Fallavier, France). $10 \mathrm{mM}$ Hepes- $150 \mathrm{mM} \mathrm{NaCl}$ buffer at $\mathrm{pH} 7.4$ was prepared to dissolve polyelectrolytes and TCEP using ultrapure water (MilliQ- plus system, Millipore) with a resistivity of $18.2 \mathrm{M} \Omega . \mathrm{cm}$. All polyelectrolyte solutions were prepared at $0.5 \mathrm{mg} / \mathrm{mL}$ by dissolution of adequate amounts of polyelectrolyte powders in Hepes- $\mathrm{NaCl}$ buffer. The solutions were freshly prepared before use.

Quartz crystal microbalance. The construction of multilayer films was monitored in situ by quartz crystal microbalance with dissipation monitoring QCM (Q-Sense E4, Götenborg, Sweden). The QCM technique consists in measuring the resonance frequency changes $\left(\Delta f_{v}\right)$ induced by polyelectrolyte adsorption on a quartz crystal. The quartz crystal is excited at its fundamental frequency $(5 \mathrm{MHz})$, and the measurements are performed at the first, third, fifth and seventh overtones (denoted by $v=1,3,5$ and 7, respectively) corresponding to about 5, 15, 25, and $35 \mathrm{MHz}$, respectively. Changes in the resonance frequencies, $\Delta f_{v}$ once the excitation is switched off are measured at these four frequencies. The quartz crystals used here are coated with a $\sim 50 \mathrm{~nm} \mathrm{SiO}{ }_{2}$ film. The sensor is fixed in removable flow modules with inlet and outlet and maintained at $22^{\circ} \mathrm{C}$. In each experiment, $600 \mu \mathrm{L}$ of $\mathrm{Hepes}-\mathrm{NaCl}$ solution were injected into the measurement cell. After stabilization of the signals (shift in reduced frequency typically lower than $0.5 \mathrm{~Hz} / \mathrm{min}$ ), $600 \mu \mathrm{L}$ of the polycation solution dissolved in a Hepes$\mathrm{NaCl}$ buffer was injected. This solution was left in the cell for $5 \mathrm{~min}$, and rinsed with the Hepes- $\mathrm{NaCl}$ buffer and left again for $5 \mathrm{~min}$. During the whole process, the frequency shifts were continuously recorded as a function of time. The same procedure was used for the deposition of the polyanion. The construction was pursued by alternate depositions of polycation and polyanion. A positive shift in the opposite of the normalized frequency shift, $-\Delta f_{v} / v$, can be associated, in first approximation, with an increase of the mass adsorbed on the crystal. In our case; the normalized frequency shifts (15, 25 and 35 $\mathrm{MHz}$ ) are superimposed then the Sauerbrey's relation can be applied to determine the thickness adsorbed. $^{43}$

Buildup of multilayered films on glass coverslips. Polyelectrolyte multilayers films have been prepared in 24 wells plates on glass coverslips (VWR, Strasbourg, France) pretreated with $0.1 \mathrm{M}$ SDS for $15 \mathrm{~min}$ followed by $0.1 \mathrm{M} \mathrm{HCl}$ for $15 \mathrm{~min}$ at $100^{\circ} \mathrm{C}$ and rinsed with extensively distilled water between each treatment. $300 \mu \mathrm{L}$ of polycation solution were deposited for 10 min on glass coverslips followed by three rinses with Hepes- $\mathrm{NaCl}$ buffer. Then, $300 \mu \mathrm{L}$ of polyanionic solution were added for $10 \mathrm{~min}$ followed by three rinses. These steps were repeated according to the chosen film scheme, typically $(\mathrm{PAH} / \mathrm{PSS})_{\mathrm{n}}-\mathrm{PAH}$ and $\left(\mathrm{PVBANH}_{3}{ }^{+} / \mathrm{PVBACOO}^{-}\right)_{\mathrm{m}}-(\mathrm{PAH} / \mathrm{PSS})_{\mathrm{n}}-\mathrm{PAH}$ films.

Cell culture on multilayer films. Gingival fibroblasts (HGFs) were isolated from human gingival connective tissue of healthy individuals according to a protocol approved by the ethics committee for patient protection of CPP Strasbourg Hospitals. Gingival tissues were obtained from gingival samples without inflammation removed for tooth extraction purposes, cut into small pieces, placed into culture dishes, and incubated in a humidified atmosphere of $95 \%$ air and $5 \% \mathrm{CO}_{2}$ at $37^{\circ} \mathrm{C}$ for 30 min. Then, culture medium (DMEM with $20 \%$ FBS, $100 \mu \mathrm{g} / \mathrm{mL}$ penicillin-streptomycin and $2 \mu \mathrm{g} / \mathrm{mL}$ Fungizone ${ }^{\circledR}$, Gibco) was added. After reaching confluency, the cells were harvested using $0.25 \%$ trypsin. HGFs were used between the $4^{\text {th }}$ and $6^{\text {th }}$ passage. For phenotype characterization, HGFs were seeded in 24 wells plates at the density of $3 \times 10^{4}$ cells per $\mathrm{cm}^{2}$ over glass coverslips covered with different architectures.

Detachment of HGFs cell sheet. After 30 days of HGFs culture on $\left(\mathrm{PVBANH}_{3}{ }^{+} / \mathrm{PVBACOO}^{-}\right)_{10^{-}}$ (PAH/PSS) $10-\mathrm{PAH}$ film, the cell layer was detached by contact with TCEP during less than 30 minutes. Tweezers were used to peel the cell sheet. After detachment, the cell sheet was immersed on cell culture medium. 
Viability assay. The measurement of cell viability was done by the AlamarBlue ${ }^{\mathrm{TM}}$ assay (Biosource International). This assay is based on the reduction of the blue, non fluorescent dye resazurin to the pink and fluorescent dye resorufin by living cells. Viability was assessed for different times. After rinsing cells with PBS $10 \%$ reagent in complete medium was incubated for 3 hours. After incubation optical density (OD) at $570 \mathrm{~nm}$ and $630 \mathrm{~nm}$ were determined with a microplate reader. The percentage of reduction of AlamarBlue ${ }^{\mathrm{TM}}$ was calculated according to the procedure provided by the manufacturer.

Immunocytochemical detection of collagen type I, F-actin, MMP2 and alpha-actin. Cells were fixed with $3.7 \%$ paraformaldehyde for $10 \mathrm{~min}$ at $4^{\circ} \mathrm{C}$, permeabilized in $0.25 \%$ Triton X-100 in PBS for 10 min, and blocked in 1\% BSA-PBS for $30 \mathrm{~min}$. Thereafter, cells were incubated for 3 hours at room temperature with rabbit anti-collagen type I (COL1) antibody (Ab-cam), mouse monoclonal anti-human smooth muscle $\alpha$-actin ( $\alpha$-SMA) (Dako), or anti-metalloprotease 2 (MMP2) at the dilution of 1/200 and 1/50 respectively. Slides were then extensively washed with PBS, and a secondary antibody (Invitrogen Alexa fluor anti-rabbit IgG or Rockland goat polyclonal FITC anti-mouse IgG, respectively) was added at a dilution of 1/1000 and incubated for 2 hours at room temperature in the dark, followed by nuclear counterstaining with DAPI $(50 \mathrm{ng} / \mathrm{ml})$ (Invitrogen) incubated for $2 \mathrm{~min}$ at room temperature. F-actin filaments were observed by incubation of cells for $30 \mathrm{~min}$ at room temperature with $5 \times 10^{-5} \mathrm{mg} / \mathrm{mL}$ phalloidin-tetramethylrhodamine B isothiocyanate (Sigma-Aldrich). Washed slides were mounted on blades with DAKO fluorescent mounting medium (DAKO) and fluorescence distribution was examined by means of an inverse fluorescence microscope (Axiovert, Zeiss).

Quantitative Real-time Reverse Transcriptase Polymerase Chain Reaction ( $q R T-P C R)$. Total RNA was isolated from the cells on each well after trypsin extraction with the RNeasy Mini Kit from QIAGEN. The amount of RNA in each sample was quantified using a NanoDrop spectrophotometer (Thermo Scientific) and adjusted at $150 \mathrm{ng} / \mu \mathrm{L}$. cDNA strand was generated from $10 \mu \mathrm{L}$ total RNA using the Superscript II kit from Invitrogen. The amplification of cDNAs was performed in separate reactions of 40 cycles each in a Biorad PCR system (Bio-Rad MyiQ ${ }^{\mathrm{TM}} 2$ Two-Color Real-Time PCR Detection System) using the Quantitec SYBR Green PCR Kit and gene-specific primer pairs (QuantiTec Primer) from QIAGEN for $\alpha$-SMA, and the beta2 microglobulin (BM2), hypoxanthine phosphoribosyl transferase1 (HPRT1) and glyceraldehyde phosphate dehydrogenase (GAPDH) housekeeping gene controls. Gene expression level stability was analyzed by the GeNorm algorithm. The experiment was repeated three times and the analysis of marker expression was performed using the $\mathrm{iQ}^{\mathrm{TM}} 5 \mathrm{Optical}^{\mathrm{T}}$ System Software.

\section{References}

1. Shimizu, T.; Yamato, M.; Kikuchi, A.; Okano, T. Biomaterials 2003, 24, (13), 2309-2316.

2. Nichol, J. W.; Khademhosseini, A. Soft Matter 2009, 5, (7), 1312-1319.

3. Yang, J.; Yamato, M.; Kohno, C.; Nishimoto, A.; Sekine, H.; Fukai, F.; Okano, T. Biomaterials 2005, 26, (33), 6415-6422.

4. $\quad$ Okano, T.; Yamada, N.; Okuhara, M.; Sakai, H.; Sakurai, Y. Biomaterials 1995, 16, (4), $297-$

303.

5. Elloumi-Hannachi, I.; Yamato, M.; Okano, T. J. Intern. Med. 2010, 267, (1), 54-70.

6. Iwasaki, K.; Kojima, K.; Kodama, S.; Paz, A. C.; Chambers, M.; Umezu, M.; Vacanti, C. A. Circulation 2008, 118, (14), S52-S57.

7. $\quad$ Chong, M. S. K.; Chan, J.; Choolani, M.; Lee, C. N.; Teoh, S. H. Biomaterials 2009, 30, (12), 2241-2251.

8. Nagai, N.; Yunoki, S.; Satoh, Y.; Tajima, K.; Munekata, M. J. Biosci. Bioeng. 2004, 98, (6), 493-496.

9. Ito, A.; Ino, K.; Kobayashi, T.; Honda, H. Biomaterials 2005, 26, (31), 6185-6193.

10. Guillaume-Gentil, O.; Akiyama, Y.; Schuler, M.; Tang, C.; Textor, M.; Yamato, M.; Okano, T.; Voros, J. Adv. Mater. 2008, 20, (3), 560-565. 
11. Inaba, R.; Khademhosseini, A.; Suzuki, H.; Fukuda, J. Biomaterials 2009, 30, (21), 3573-3579.

12. Seto, Y.; Inaba, R.; Okuyama, T.; Sassa, F.; Suzuki, H.; Fukuda, J. Biomaterials 2010, 31, (8), 2209-2215.

13. Isenberg, B. C.; Tsuda, Y.; Williams, C.; Shimizu, T.; Yamato, M.; Okano, T.; Wong, J. Y. Biomaterials 2008, 29, (17), 2565-2572.

14. Bostman, O.; Pihlajamaki, H. Biomaterials 2000, 21, (24), 2615-2621.

15. Gilbert, T. W.; Stewart-Akers, A. M.; Badylak, S. F. Biomaterials 2007, 28, (2), 147-150.

16. Falco, E. E.; Patel, M.; Fisher, J. P. Pharm. Res. 2008, 25, (10), 2348-2356.

17. Decher, G. Science 1997, 277, (5330), 1232-1237.

18. Caruso, F.; Niikura, K.; Furlong, D. N.; Okahata, Y. Langmuir 1997, 13, (13), 3422-3426.

19. Tryoen-Toth, P.; Vautier, D.; Haikel, Y.; Voegel, J. C.; Schaaf, P.; Chluba, J.; Ogier, J. J.

Biomed. Mater. Res. 2002, 60, (4), 657-67.

20. Boura, C.; Menu, P.; Payan, E.; Picart, C.; Voegel, J.-C.; Muller, S.; Stoltz, J. F. Biomaterials 2003, 24 3521-3530.

21. Boura, C.; Muller, S.; Vautier, D.; Dumas, D.; Schaaf, P.; Voegel, J. C.; Stoltz, J. F.; Menu, P. Biomaterials 2005, 26, (22), 4568-4575.

22. Moby, V.; Boura, C.; Kerdjoudj, H.; Voegel, J. C.; Marchal, L.; Dumas, D.; Schaaf, P.; Stoltz, J. F.; Menu, P. Biomacromolecules 2007, 8, (7), 2156-2160.

23. Kerdjoudj, H.; Boura, C.; Moby, V.; Montagne, K.; Schaaf, P.; Voegel, J. C.; Stoltz, J. F.; Menu, P. Adv. Funct. Mater. 2007, 17, (15), 2667-2673.

24. Kerdjoudj, H.; Berthelemy, N.; Rinckenbach, S.; Kearney-Schwartz, A.; Montagne, K.; Schaaf, P.; Lacolley, P.; Stoltz, J. F.; Voegel, J. C.; Menu, P. J. Am. Coll. Card. 2008, 52, (19), 1589-1597.

25. Thebaud, N. B.; Bareille, R.; Daculsi, R.; Bourget, C.; Remy, M.; Kerdjoudj, H.; Menu, P.; Bordenave, L. Acta Biomaterialia 2010, 6, (4), 1437-1445.

26. Berthelemy, N.; Kerdjoudj, H.; Gaucher, C.; Schaaf, P.; Stoltz, J. F.; Lacolley, P.; Voegel, J.-C.; Menu, P. Adv. Mater. 2008, 20 2674-2679.

27. Berthelemy, N.; Kerdjoudj, H.; Schaaf, P.; Prin-Mathieu, C.; Lacolley, P.; Stoltz, J. F.; Voegel, J. C.; Menu, P. PLoS One 2009, 4, e5514.

28. Liao, T. Q.; Moussallem, M. D.; Kim, J.; Schlenoff, J. B.; Ma, T. Biothechnol. Progr. 2010, 26, (6), 1705-1713.

29. Mamedov, A. A.; Kotov, N. A. Langmuir 2000, 16, (13), 5530-5533.

30. Lavalle, P.; Boulmedais, F.; Ball, V.; Mutterer, J.; Schaaf, P.; Voegel, J.-C. J. Membr. Sci. 2005, 253, (1-2), 49-56.

31. Buck, M. E.; Lynn, D. M. Langmuir 2010, 26, (20), 16134-16140.

32. Chen, J.; Xia, X. M.; Huang, S. W.; Zhuo, R. X. Adv. Mater. 2007, 19, (7), 979-983.

33. Saito, G.; Swanson, J. A.; Lee, K. D. Adv. Drug. Del. Rev. 2003, 55, (2), 199-215.

34. Zelikin, A. N.; Quinn, J. F.; Caruso, F. Biomacromolecules 2006, 7, (1), 27-30.

35. El-Sayed, M. E. H.; Hoffman, A. S.; Stayton, P. S. J. Control. Rel. 2005, 101, (1-3), 47-58.

36. McKenzie, D. L.; Smiley, E.; Kwok, K. Y.; Rice, K. G. Bioconjugate Chem. 2000, 11, (6), 901-

909.

37. Park, Y.; Kwok, K. Y.; Boukarim, C.; Rice, K. G. Bioconjugate Chem. 2002, 13, (2), 232-239.

38. Nakajima, K.; Abe, T.; Tanaka, M.; Hara, Y. J. Peridont. Res. 2008, 43, (6), 681-688.

39. Hinz, B.; Celetta, G.; Tomasek, J. J.; Gabbiani, G.; Chaponnier, C. Mol Biol Cell 2001, 12, 2730-2741.

40. Turabelidze, A.; Guo, S. J.; DiPietro, L. A. Wound. Rep. Reg. 2010, 18, (5), 460-466.

41. Tomasek, J. J.; Gabbiani, G.; Hinz, B.; Chaponnier, C.; Brown, R. A. Nat. Rev. Mol. Cell Bio. 2002, 3, (5), 349-363.

42. Guillaume-Gentil, O.; Semenov, O. V.; Zisch, A. H.; Zimmermann, R.; Voros, J.; Ehrbar, M. Biomaterials 2011, 32, (19), 4376-4384.

43. Sauerbrey, G. Z. Phys. 1959, 155, 206-222. 